\title{
The incidence and clinical effects of Bordetella pertussis in children hospitalized with acute bronchiolitis
}

\author{
Emilya Efendiyeva $^{1 \oplus}$, Tuğçe Tural Kara ${ }^{2 \odot}$, Tuğba Erat ${ }^{2 \odot}$, Aysun Yahşi ${ }^{2 \odot}$, \\ Adem Karbuz ${ }^{2 \oplus}$, Bilge Aldemir Kocabaş ${ }^{2 \oplus}$, Halil Özdemir ${ }^{2 \odot}$, \\ Zeynep Ceren Karahan $^{3 \odot}$, Erdal İnce ${ }^{2 \odot}$, Ergin Çiftçi ${ }^{2 \odot}$ \\ ${ }^{2}$ Division of Pediatric Infectious Diseases, ${ }^{1}$ Department of Pediatrics and ${ }^{3}$ Department of Medical Microbiology, Ankara University \\ Faculty of Medicine, Ankara, Turkey.
}

\begin{abstract}
Background. Pertussis is a disease leading to high morbidity and mortality in neonates and infants. Bronchiolitis is the most common cause of hospitalization especially in children $<2$ year-old. Although the clinical findings are different in these two diseases, it is sometimes difficult to make this distinction in partially or fully vaccinated children. This study aimed to identify the incidence, clinical and laboratory effects of B. pertussis as a causative agent in hospitalized children with acute bronchiolitis.
\end{abstract}

Methods. The study included patients diagnosed with acute bronchiolitis and admitted to the Division of Pediatric Infectious Diseases from January 2012 to December 2015, aged 24 months or younger, evaluated for viruses and bacteria with polymerase chain reaction in respiratory tract secretions.

Results. The study included 380 patients hospitalized with acute bronchiolitis. Of these patients, $85.8 \%$ were identified to be positive for at least one respiratory pathogen. The most commonly identified pathogens were respiratory syncytial virus (RSV) A/B, rhinovirus, parainfluenza virus, adenovirus, bocavirus and metapneumovirus A/B. B. pertussis was only detected in 5 patients $(1.5 \%)$. In the patients with $B$. pertussis identified, coinfection with another virus was observed including rhinovirus $(n=2)$, influenza $A$ virus ( $n=1)$, coronavirus OC43 (n=1) and RSV A/B (n=1). The presence of B. pertussis did not appear to cause any significant clinical or laboratory differences in patients.

Conclusions. B. pertussis is a rare pathogen in patients admitted to hospital for acute bronchiolitis. However, in patients who do not respond to standard bronchiolitis treatment, B. pertussis should be considered as a causative agent. Early identification of this pathogen is important in terms of quarantining the patient, administering appropriate antimicrobial treatment, and prophylactic treatment to household and other close contacts.

Key words: acute bronchiolitis, Bordetella pertussis, hospitalized children, incidence.

Acute bronchiolitis is the most common lower respiratory tract disease which occurs due to inflammatory obstruction of the small airways in children. Generally, it is observed in the first 2 years of life. ${ }^{1}$ Respiratory syncytial virus (RSV) is responsible for $>80 \%$ of lower respiratory tract infections in children younger than 1 year. $^{2}$

\footnotetext{
Tuğçe Tural Kara

tugcetural@hotmail.com
}

Received 15th May 2019, revised 20th January 2020, accepted 15th February 2020.
Pertussis or whooping cough is an endemic disease with high morbidity and mortality in infants caused by Bordetella pertussis. Globally, nearly 16 million pertussis cases are observed each year and it causes 195,000 deaths. Pertussis typically causes a clinical picture characterized by three periods of catarrhal, paroxysmal and convalescent stages. Since the implementation of vaccinations, this classic clinical progression is observed less frequently. ${ }^{3}$

In patients presenting with bronchiolitis, coinfections caused by more than one 
respiratory tract viruses may be seen. Similarly, B. pertussis can also be detected with respiratory tract viruses. However, there are different data in the literature about the frequency of pertussis in young children with bronchiolitis. Although the frequency is reported as high in some studies; it is detected too low in others. ${ }^{4-9}$ This study aimed to identify the incidence of B. pertussis as pathogen in children with acute bronchiolitis, and to research the effect of its presence on clinical and laboratory features.

\section{Material and Methods}

The study included patients admitted to the Division of Pediatric Infectious Disease from January 2012 to December 2015 diagnosed with acute bronchiolitis, aged 24 months or younger, evaluated for both viruses and bacteria with polymerase chain reaction (PCR) in respiratory tract secretions. Within the first 48 hours of admission to hospital, patients had nasopharyngeal secretion samples taken with aspiration and were evaluated for the following viruses; RVS A/B, rhinovirus, adenovirus, bocavirus, metapneumovirus $\mathrm{A} / \mathrm{B}$, parainfluenza virus $1,2,3,4$, coronavirus 229E, NL63, OC43, HKU1, influenza virus A/B, H1N1, enterovirus and parechovirus) and bacteria; B. pertussis, Mycoplasma pneumoniae, Legionella pneumophila, Chlamydophila pneumoniae, Streptococcus pneumoniae, Haemophilus influenzae with the PCR method.

Statistical assessment was completed with the Statistical Package for Social Sciences (SPSS) Windows 20 (IBM SPSS Inc., Chicago, IL). Normal distribution of data was analyzed with the Kolmogorov-Smirnov test. As numerical variables did not display normal distribution, they are shown as median (interval; min-max). Differences between numerical variables in two category groups were examined with the Mann-Whitney U test. For all analyses, $\mathrm{p}<0.05$ was accepted as statistically significant.

Informed consent was obtained from the patients included in the study. The study was approved by the local ethics committee with number of 12-560-16 (27/06/2016).

\section{Results}

Of 847 patients admitted to hospital with acute bronchiolitis diagnosis, a total of 380 patients aged 24 months or younger with PCR investigation of respiratory tract secretions for viruses and bacteria were included in the study. Of the patients 161 (42.4\%) were girls and 219 $(57.6 \%)$ were boys. The median age of diagnosis was 4 months (range; 1-23 months).

Of the 380 patients, 326 patients $(85.8 \%)$ were identified to be positive for at least one respiratory pathogen. B. pertussis was detected in $5(1.5 \%)$ of these patients. Significant differences were not observed between $B$. pertussis positive and negative patients in terms of gender, age of diagnosis, history of prematurity, previous attendance at health organizations, presence of individuals with cough in the family and vaccination history $(\mathrm{p}>0.05)$ (Table I).

The most common agents were $S$. pneumoniae (66.3\%), H. influenzae (43.9\%), RVS A/B (53.7\%) and rhinovirus $(25.3 \%)$ in children admitted to the hospital for acute bronchiolitis. Coinfections with more than one virus were identified in 93 $(24.5 \%)$ patients. The most common of these were rhinovirus and RSV A/B (4.5\%) and rhinovirus and adenovirus (2.4\%). Simultaneously detected pathogens in patients with $B$. pertussis were as follows; influenza $A(n=1)$, coronavirus OC43 (n= 1), RSV A/B (n=1), rhinovirus $(\mathrm{n}=2)$, M. pneumoniae $(\mathrm{n}=1)$, S. pneumoniae $(\mathrm{n}=2)$ and $H$. influenzae $(\mathrm{n}=3)$. The demographic, clinical and laboratory characteristics of patients with B. pertussis are given in Table II.

Significant differences were not identified in terms of clinical, radiologic and laboratory findings of patients according to the presence of B. pertussis $(\mathrm{p}>0.05)$ (Table III). The proportion of patients positive for $B$. pertussis with white cell count above 10,000 was $60 \%$, while this rate was $54.5 \%$ for $B$. pertussis negative patients ( $\mathrm{p}=$ 0.807 ). For white cell counts above 15,000 , the 
Table I. Demographic findings of patients according to Bordetella pertussis positivity.

\begin{tabular}{|c|c|c|c|}
\hline \multirow[b]{2}{*}{ Variables } & \multicolumn{2}{|c|}{ Bordetella pertussis } & \multirow[b]{2}{*}{$\mathrm{p}$} \\
\hline & $\begin{array}{c}\text { Negative } \\
(\mathrm{n}=321)\end{array}$ & $\begin{array}{l}\text { Positive } \\
\quad(\mathrm{n}=5)\end{array}$ & \\
\hline \multicolumn{4}{|l|}{ Gender* } \\
\hline Female & $137(42.7)$ & $2(40.0)$ & \multirow{2}{*}{0.904} \\
\hline Male & $184(57.3)$ & $3(60.0)$ & \\
\hline Age of diagnosis (months) ${ }^{* *}$ & $4(1-23)$ & $4(1-13)$ & 0.765 \\
\hline Prematurity ${ }^{*}$ & $26(8.1)$ & - & - \\
\hline Previous admission to another health center* & $150(46.7)$ & $4(80.0)$ & 0.193 \\
\hline \multicolumn{4}{|l|}{ Household member with cough* } \\
\hline None & $47(14.6)$ & - & \multirow{3}{*}{0.574} \\
\hline Unknown & $109(34.0)$ & $1(20.0)$ & \\
\hline Yes & $165(51.4)$ & $4(80.0)$ & \\
\hline Mother & $20(12.1)$ & $1(25.0)$ & \multirow{6}{*}{0.934} \\
\hline Father & $9(5.5)$ & - & \\
\hline Siblings & $60(36.4)$ & $1(25.0)$ & \\
\hline Others & $9(5.5)$ & - & \\
\hline Several people & $31(18.8)$ & $1(25.0)$ & \\
\hline Unknown & $36(21.8)$ & $1(25.0)$ & \\
\hline \multicolumn{4}{|l|}{ Number of pertussis vaccines* } \\
\hline None & $74(23.1)$ & $1(20.0)$ & \multirow{6}{*}{0.512} \\
\hline 1 & $75(23.4)$ & $1(20.0)$ & \\
\hline 2 & $40(12.5)$ & $2(40.0)$ & \\
\hline 3 & $112(34.9)$ & $1(20.0)$ & \\
\hline 4 & $19(5.9)$ & - & \\
\hline Uncertain & $1(0.3)$ & - & \\
\hline
\end{tabular}

* Categoric variables shown as number (\%)

** Numerical variables without normal distribution shown as median (min-max)

rate was $20 \%$ for patients positive for $B$. pertussis and $19.6 \%$ for B. pertussis negative patients $(\mathrm{p}=$ 0.993).

In this study, the most frequent admissions occurred in January and February (19.7\%), followed by December (11.8\%). Median hospital stay was 5 days (interval; $1-43$ days). B. pertussis positive patients were admitted in February, March, May, August and October. Median hospital stay for $B$. pertussis patients positive was 4 days (interval: 2-10 days), while it was 5 days for $B$. pertussis negative patients (interval: $1-43$ days $)(p=0.778)$.

Of patients admitted for acute bronchiolitis, $12.1 \%(n=46)$ were hospitalized in intensive care units and median duration of hospitalization was 3 days (interval: 1-37 days). Of patients, $10.5 \%(n=40)$ required mechanical ventilation. The rate of patients readmitted within one month after discharge was $7.6 \%(n=29)$. None of the patients positive for $B$. pertussis was admitted to the intensive care unit. All $B$. pertussis positive patients received oxygen, oral salbutamol and oral clarithromycin therapy during hospitalization. The rate of use of clarithromycin among patients positive for $B$. pertussis was $100 \%$, while it was $24.6 \%$ for $B$. pertussis negative patients $(\mathrm{p}=0.016)$. There were no significant differences for other administered treatments in terms of the presence of $B$. pertussis. 
Table II. Demographic, clinical and laboratory characteristics of patients positive for Bordetella pertussis.

\begin{tabular}{|c|c|c|c|c|c|}
\hline Variables & Patient 1 & Patient 2 & Patient 3 & Patient 4 & Patient 5 \\
\hline Age (months) & 13 & 1 & 5 & 4 & 3 \\
\hline Gender & Male & Female & Male & Female & Male \\
\hline $\begin{array}{l}\text { Year/month } \\
\text { admitted to } \\
\text { hospital }\end{array}$ & 2015/August & 2014/February & 2013/March & 2013/May & 2014/October \\
\hline $\begin{array}{l}\text { Duration of } \\
\text { complaint (days) }\end{array}$ & 6 & 2 & 7 & 21 & 13 \\
\hline $\begin{array}{l}\text { Dose of pertussis } \\
\text { vaccination }\end{array}$ & 3 & 0 & 2 & 2 & 1 \\
\hline Clinical findings & $\begin{array}{l}\text { Fever, cough, } \\
\text { rhinitis }\end{array}$ & Cough, rhinitis & $\begin{array}{l}\text { Fever, cough, } \\
\text { rhinitis, wheeze }\end{array}$ & Cough, wheeze & $\begin{array}{l}\text { Cough, rhinitis, } \\
\text { vomiting, facial } \\
\text { flushing, wheeze }\end{array}$ \\
\hline $\begin{array}{l}\text { Physical } \\
\text { examination } \\
\text { findings }\end{array}$ & $\begin{array}{l}\text { Tachypnea, } \\
\text { retraction, } \\
\text { prolonged } \\
\text { expirium, } \\
\text { rhonchi, rales }\end{array}$ & $\begin{array}{l}\text { Prolonged } \\
\text { expirium, } \\
\text { rhonchi }\end{array}$ & $\begin{array}{l}\text { Tachypnea, } \\
\text { retraction, } \\
\text { prolonged } \\
\text { expirium, } \\
\text { rhonchi, rales }\end{array}$ & $\begin{array}{l}\text { Tachypnea, } \\
\text { retraction, } \\
\text { prolonged } \\
\text { expirium, rhonchi, } \\
\text { rales, wheezing }\end{array}$ & $\begin{array}{l}\text { Tachypnea, } \\
\text { prolonged } \\
\text { expirium }\end{array}$ \\
\hline $\begin{array}{l}\text { Chest radiography } \\
\text { findings }\end{array}$ & Infiltration & Hyperinflation & $\begin{array}{l}\text { Infiltration + } \\
\text { Hyperinflation }\end{array}$ & $\begin{array}{l}\text { Infiltration }+ \\
\text { Hyperinflation }\end{array}$ & Hyperinflation \\
\hline $\begin{array}{l}\text { White cell/ } \\
\text { lymphocyte count } \\
\left(/ \mathrm{mm}^{3}\right)\end{array}$ & $11100 / 3100$ & $9300 / 6900$ & $15300 / 6700$ & $7300 / 2600$ & $10600 / 6600$ \\
\hline $\begin{array}{l}\text { ESR/CRP values } \\
(\mathrm{mm} / \mathrm{h}, \mathrm{mg} / \mathrm{L})\end{array}$ & $16 / 16.6$ & $44 / 1$ & $68 / 45.1$ & $10 / 1$ & $6 / 1$ \\
\hline Coinfections & $\begin{array}{l}\text { Mycoplasma } \\
\text { pneumoniae }\end{array}$ & $\begin{array}{l}\text { RSV, } \\
\text { influenza A }\end{array}$ & $\begin{array}{l}\text { Rhinovirus, } \\
\text { S.pneumoniae, } \\
\text { H.influenzae }\end{array}$ & $\begin{array}{l}\text { Coronavirus } \\
\text { OC43, } \\
\text { H. influenzae }\end{array}$ & $\begin{array}{l}\text { Rhinovirus, } \\
\text { S.pneumoniae, } \\
\text { H.influenzae }\end{array}$ \\
\hline $\begin{array}{l}\text { Bronchodilator / } \\
\text { steroid treatment }\end{array}$ & $+/+$ & $+/-$ & $+/+$ & $+/+$ & $+/+$ \\
\hline $\begin{array}{l}\text { Antibiotic } \\
\text { treatment received }\end{array}$ & Clarithromycin & Clarithromycin & $\begin{array}{l}\text { Clarithromycin, } \\
\text { SAM }\end{array}$ & Clarithromycin & Clarithromycin \\
\hline
\end{tabular}

ESR: estimated sedimentation rate, CRP: $\mathrm{C}$ reactive protein

\section{Discussion}

Pertussis may result in severe progression in infants and children. Although the effective development of vaccination programs, globally each year it still causes millions of cases and thousands of deaths. ${ }^{10}$ Acute bronchiolitis is the most common cause of hospitalization in children under 2 years of age. ${ }^{11}$ Today, there is a great interest in the presence of pertussis in children hospitalized due to acute bronchiolitis and its effect on the clinical status. The detection of causative pathogens in respiratory tract infections by molecular methods and the lifethreatening conditions of these two diseases in young children have aroused interest in the association of pertussis infection in hospitalized patients. In our study, B. pertussis was identified in only 5 patients; this suggests that it is a rare pathogen in patients with acute bronchiolitis. Many physicians prescribe macrolide treatment considering the possibility of pertussis in patients hospitalized. This in turn increases the use of macrolide antibiotics and contributes to 
Table III. Clinical, physical examination, laboratory and imaging findings of patients according to Bordetella pertussis.

\begin{tabular}{|c|c|c|c|}
\hline \multirow[b]{2}{*}{ Variables } & \multicolumn{2}{|c|}{ Bordetella pertussis } & \multirow[b]{2}{*}{$\mathrm{p}$} \\
\hline & $\begin{array}{c}\text { Negative } \\
(\mathrm{n}=321)\end{array}$ & $\begin{array}{l}\text { Positive } \\
(\mathrm{n}=5)\end{array}$ & \\
\hline \multicolumn{4}{|l|}{ Clinical findings } \\
\hline Cough* & $321(100)$ & $5(100)$ & - \\
\hline Rhinitis* & $240(74.8)$ & $4(80.0)$ & 0.789 \\
\hline Wheeze* & $226(70.4)$ & $3(60.0)$ & 0.636 \\
\hline Fever* & $153(47.7)$ & $2(40.0)$ & 0.733 \\
\hline Vomiting after cough* & $27(8.4)$ & $1(20.0)$ & 0.364 \\
\hline Facial flushing during cough* & $29(9.0)$ & $1(20.0)$ & 0.385 \\
\hline Conjunctival redness* & $2(0.6)$ & $0(0)$ & 0.859 \\
\hline Facial swelling* & $0(0)$ & $0(0)$ & \\
\hline Suspiration* & $0(0)$ & $0(0)$ & \\
\hline \multicolumn{4}{|l|}{ Physical examination findings } \\
\hline Prolonged expirium* & $316(98.4)$ & $5(100.0)$ & 0.779 \\
\hline Rhonchi* & $26(83.5)$ & $4(80.0)$ & 0.836 \\
\hline Rales* & 247 (76.9) & $3(60.0)$ & 0.331 \\
\hline Tachypnea* & $235(73.2)$ & $3(60.0)$ & 0.614 \\
\hline Retraction & $204(63.6)$ & $3(60.0)$ & 0.870 \\
\hline Wheezing* & $46(14.3)$ & $1(20.0)$ & 0.543 \\
\hline Apnea* & $6(1.9)$ & $0(0)$ & 0.758 \\
\hline \multicolumn{4}{|l|}{ Radiological findings } \\
\hline Hyperinflation* & $253(79.1)$ & $4(80.0)$ & 0.959 \\
\hline Infiltration* & $158(49.4)$ & $3(60.0)$ & 0.683 \\
\hline Atelectasis* & 35 (10.9) & $0(0)$ & 0.434 \\
\hline \multicolumn{4}{|l|}{ Laboratory findings } \\
\hline White cell $(\times 103)^{* *}$ & $10.6(1.3-28.6)$ & $10.6(7.3-15.3)$ & 0.819 \\
\hline Lymphocytes $(x 103)^{* *}$ & $4.5(0.9-16.5)$ & $6.6(2.6-6.9)$ & 0.686 \\
\hline Platelets $(\times 103)^{* *}$ & $369(39-896)$ & $342(269-764)$ & 0.720 \\
\hline Eosinophil ${ }^{* *}$ & $100(0-1300)$ & $300(0-800)$ & 0.194 \\
\hline Erythrocyte sedimentation rate & $20(0-122)$ & $16(6-68)$ & 0.493 \\
\hline C-reactive protein ${ }^{* *}$ & $6.1(0-117.2)$ & $1(1-45.1)$ & 0.532 \\
\hline
\end{tabular}

* Categorical variables shown as number (\%)

** Numerical variables shown as median (min-mix)

the development of resistance. In our study, we have concluded that the frequency of pertussis is low in patients hospitalized due to acute bronchiolitis in the hospital and therefore macrolides should not be used unnecessarily.

Our findings are similar to Piedra et al.' $\mathrm{s}^{4}$ study that identified only 4 cases ( $0.2 \%)$ among 2207 hospitalized children aged less than 2 year- old with acute bronchiolitis, whereas RSV was found in $72 \%$ of all children. In Korppi et al.' $\mathrm{s}^{5}$ study respiratory viruses were responsible for $89 \%$ acute bronchiolitis in infants hospitalized aged under 6-months of age. RSV was found in $71 \%$ of cases, and B. pertussis was not detected in any patient. Similarly, Abu Raya et al. ${ }^{6}$ analyzed 309 hospitalized children with bronchiolitis aged $\leq 2$ years of age They found 
that $7.7 \%$ of cases with B. pertussis and $67 \%$ of cases with RSV were hospitalized during the 2005-2006 peak acute bronchiolitis season. Just like the above studies Siberry et al. ${ }^{7}$ identified only 1 of 166 patients admitted to the hospital with respiratory symptoms to have a positive B. pertussis PCR result during the RSV season. In contrast to these studies that found $B$. pertussis to be rarely detected in patients with acute bronchiolitis, in the literature, different data concerning the frequency is present. In Gökçe's et al. ${ }^{8}$ study from Turkey, B. pertussis was identified $44(25.6 \%)$ of 172 infants aged $<6$ months old and coinfection with other viruses was detected in 17 (38.6\%) of 44 patients. Additionally, $51.1 \%$ of all infants had RSV which was a commonly isolated pathogen. The authors suggested that this high prevalence of B. pertussis was due to the fact that the patients had either not received any or only a single dose of the pertussis vaccine due to their small age. Another study in Finland reported that RSV was the most common causative pathogen and B. pertussisis was detected in $12(8.5 \%)$ of 142 infants younger than 6 months hospitalized for acute bronchiolitis. In addition, coinfection with RSV was found in 8 of the patients with $B$. pertussis. ${ }^{9}$

Pertussis is commonly observed as coinfections with other respiratory tract pathogens. RSV with B. pertussis increases morbidity and mortality risk. ${ }^{12}$ There are limited numbers of studies assessing the association of $B$. pertussis with RSV and coinfection varies from $0-78 \% .^{4-6,13-16}$ The studies examining the relationship between RSV and B. pertussis coinfection in patients with acute bronchiolitis are summarized in Table IV.

Pertussis and acute bronchiolitis cause serious infections that require hospitalization especially in young children. In our study, the age interval for the whole population was 1.24 months, with $57.6 \%$ of patients being male. There were no significant differences identified between $B$. pertussis positive and negative patients related to gender and age.
In our research, cough was present in all patients. The rates of vomiting after coughing $(8.4 \%)$ and facial flushing during coughing $(8.9 \%)$ were low. Studies have identified the incidence of B. pertussis infection as $13-20 \%$ for patients admitted with long-term coughing complaints. ${ }^{4}$ A study encompassing the 0-16year age group in Turkey identified B. pertussis in $16.9 \%$ of patients with cough lasting more than two weeks. ${ }^{5}$

Leukocytosis along with lymphocyte dominance supports the diagnosis of pertussis. The increase in leukocyte count and degree of lymphocytosis is parallel to the severity of the disease. However, these findings are not unique to pertussis. ${ }^{17,18}$ In our study, there were no significant differences observed in terms of laboratory findings between $B$. pertussis positive and negative patients.

Radiological investigation is not a necessity for pneumonia diagnosis in children; however, observation of infiltration on chest radiographs supports pneumonia diagnosis..$^{19}$ In our study, $49.4 \%$ of patients had infiltration and $79.1 \%$ had hyperinflation observed on chest radiographs, although there were no statistically significant radiological differences observed between $B$. pertussis positive and negative patients.

The information about the seasonality of pertussis is not clear. Epidemics are mainly observed in the winter and spring months. ${ }^{4}$ Generally, the disease is endemic in the months of July to October. ${ }^{20}$ Acute bronchiolitis peaks in the winter and spring months. ${ }^{21}$ In our study, the majority of acute bronchiolitis patients were admitted to the hospital between December to May. Additionally, the majority of patients with $B$. pertussis identified were admitted from February to May. These findings lead to the consideration that admission for acute bronchiolitis accompanying $B$. pertussis increases during the winter and spring months. Though this hypothesis complies with the literature, there is a need for prospective studies with larger samples. 
Table IV. Bordetella pertussis and RSV coinfection rates in patients with acute bronchiolitis.

\begin{tabular}{|c|c|c|c|c|c|c|}
\hline Authors & Study years & $\begin{array}{l}\text { Number } \\
\text { of } \\
\text { patients }\end{array}$ & Age & $\begin{array}{c}\text { B. pertussis } \\
\mathrm{n}(\%)\end{array}$ & $\begin{array}{c}\text { BP-RSV } \\
\text { Coinfection }\end{array}$ & $\begin{array}{c}\text { B. pertussis } \\
\text { Clinical findings }\end{array}$ \\
\hline Frühwirth & 1995-1998 & 183 & $<18$ years & $71(38.8 \%)$ & - & - \\
\hline Greenberg & 1998-2001 & 74 & $<12$ months & $11(15 \%)$ & $6(54 \%)$ & No \\
\hline Crowcroft & 1999-2000 & 142 & $<5$ months & $33(23 \%)$ & $11(33 \%)$ & No \\
\hline Moore HC & 2000-2005 & 1669 & $<9$ years & $354(21.2 \%)$ & - & - \\
\hline Nuolivirta K & 2001-2004 & 205 & $<6$ months & $12(8.5 \%)$ & $8(67 \%)$ & No \\
\hline Guinto-Ocampo & 2001-2005 & 141 & $<12$ months & $18(13 \%)$ & - & No \\
\hline Cosnes-Lambe & 2005-2006 & 126 & $<4$ months & $19(15 \%)$ & $14(73 \%)$ & No \\
\hline Korppi M & 2005-2006 & 117 & $<6$ months & $9(8 \%)$ & $7(78 \%)$ & No \\
\hline Raya BA & 2005-2006 & 309 & $<24$ months & $24(7.7 \%)$ & $16(67 \%)$ & $\begin{array}{c}43 \% \text { prolonged } \\
\text { coughing }\end{array}$ \\
\hline Miron D & 2005-2006 & 465 & $<24$ months & $29(6.2 \%)$ & - & - \\
\hline Walsh PF & 2005-2006 & 204 & $<18$ months & 0 & 0 & No \\
\hline Pedro A & 2007-2010 & 2207 & $<24$ months & $4(0.2 \%)$ & $2(50 \%)$ & $\begin{array}{c}2.4 \% \text { prolonged } \\
\text { coughing }\end{array}$ \\
\hline Jolien $\mathrm{T}$ & $2007-2010$ & 3074 & $>18$ years & $93(3 \%)$ & - & $\begin{array}{l}\text { 37\% prolonged } \\
\text { coughing }\end{array}$ \\
\hline Korppi M & 2008-2010 & 408 & $<24$ months & 0 & 0 & No \\
\hline Ivana PE & 2009-2010 & 596 & $<5$ years & $114(19.2 \%)$ & $15(13.1 \%)$ & No \\
\hline Gökçe Ş & $2013-2016$ & 172 & $<6$ months & $44(25.6 \%)$ & $16(36.4 \%)$ & $\begin{array}{c}9.1 \% \text { prolonged } \\
\text { coughing }\end{array}$ \\
\hline
\end{tabular}

Supportive care is the most important approach for pertussis treatment. Sufficient hydration and nutrition are important to reduce the frequency of coughing. Antibiotic treatment can only partly reduce symptoms and prevent infectiousness by eliminating microorganisms from the nasopharynx. Macrolide antibiotics are used for treatment. ${ }^{22}$ In our study, all patients with $B$. pertussis used clarithromycin, and this was significantly high compared to the $B$. pertussis negative group.

There are some limitations of our research. Some patients did not have a viral or bacterial pathogen identified with the PCR method. These patients may have had non-infectious causes mimicking pulmonary infections like asthma or gastroesophageal reflux, or there may have been possible problems related to respiratory tract secretions not appropriately obtained, stored or studied, or infectious agents not yet identified or not included on the microbiology panel. Another limitation of the study was that we did not have data on whether patients received macrolide antibiotics before admission. PCR testing following antibiotic therapy also can result in false negative findings. Therefore, more extensive studies are needed.

In conclusion, $B$. pertussis is a rare pathogen in patients admitted to hospital for bronchiolitis. Clinical findings of pertussis may be atypical in partly-vaccinated infants and coinfection with a respiratory virus may create additional difficulties for pertussis diagnosis. For cases admitted to hospital who do not improve with conservative treatment, $B$. pertussis should be considered as a causative agent.

\section{REFERENCES}

1. Bonhoeffer J, Bär $G$, Riffelmann $M$, Solèr $M$, Heininger U. The role of Bordetella infections in patients with acute exacerbation of chronic bronchitis. Infection 2005; 33: 13-17. 
2. Piedimonte G, Perez MK. Respiratory syncytial virus infection and bronchiolitis. Pediatr Rev 2014; 35: 519-530.

3. Roggeri DP, Roggeri A, Rossi E, Cataudella S, Martini N. Impact of hospitalizations for bronchiolitis in preterm infants on long-term health care costs in Italy: a retrospective case-control study. Clinicoecon Outcomes Res 2016; 8: 407-412.

4. Piedra PA, Mansbach JM, Jewell AM, et al. Bordetella pertussis is an uncommon pathogen in children hospitalized with bronchiolitis during the winter season. Pediatr Infect Dis J 2015; 34: 566-570.

5. Korppi M, Kivistö J, Koponen P, et al. Absence of Bordetella pertussis among infants hospitalized for bronchiolitis in Finland, 2008-2010. Pediatr Infect Dis J 2016; 35: 219-221.

6. Abu Raya B, Bamberger E, Kassis I, Kugelman A, Srugo I, Miron D. Bordetella pertussis infection attenuates clinical course of acute bronchiolitis. Pediatr Infect Dis J 2013; 32: 619-621.

7. Siberry GK, Paquette NR, Ross TL, Perl TM, Valsamakis A. Low prevalence of pertussis among children admitted with respiratory symptoms during respiratory syncytial virus season. Infect Control Hosp Epidemiol 2006; 27: 95-97.

8. Gökçe S, Kurugöl Z, Aydemir SŞ, Çiçek C, Aslan A, Koturoğlu G. Bordetella pertussis infection in hospitalized infants with acute bronchiolitis. Indian J Pediatr 2018; 85: 189-193.

9. Nuolivirta K, Koponen $\mathrm{P}, \mathrm{He} \mathrm{Q}$, et al. Bordetella pertussis infection is common in nonvaccinated infants admitted for bronchiolitis. Pediatr Infect Dis J 2010; 29: 1013-1015.

10. Worrall G. Bronchiolitis. Can Fam Physician 2008; 54: 742-743.

11. Davison C, Ventre KM, Luchetti M, Randolph AG. Efficacy of interventions for bronchiolitis in critically ill infants: a systematic review and meta-analysis. Pediatr Crit Care Med 2004; 5: 482-489.

12. Walsh P, Overmeyer C, Kimmel L, et al. Prevalence of Bordetella pertussis and Bordetella parapertussis in samples submitted for RSV screening. West J Emerg Med 2008; 9: 135-140.
13. Korppi M, Hiltunen J. Pertussis is common in nonvaccinated infants hospitalized for respiratory syncytial virus infection. Pediatr Infect Dis J 2007; 26: 316-318.

14. Miron D, Srugo I, Kra-Oz Z, et al. Sole pathogen in acute bronchiolitis: is there a role for other organisms apart from respiratory syncytial virus? Pediatr Infect Dis J 2010; 29: e7-e10.

15. Walsh PF, Kimmel L, Feola M, et al. Prevalence of Bordetella pertussis and Bordetella parapertussis in infants presenting to the emergency department with bronchiolitis. J Emerg Med 2011; 40: 256-261.

16. Teepe J, Broekhuizen BDL, Ieven $M$, et al; GRACE consortium. Prevalence, diagnosis, and disease course of pertussis in adults with acute cough: a prospective, observational study in primary care. $\mathrm{Br}$ J Gen Pract 2015; 65: e662-e667.

17. Cherry JD. Pertussis in young infants throughout the World. Clin Infect Dis 2016; 63(Suppl 4): S119-S122.

18. Carbonetti NH. Pertussis leukocytosis: mechanisms, clinical relevance and treatment. Pathog Dis 2016; 74: ftw087.

19. Yates B, Murphy DM, Forrest IA, et al. Azithromycin reverses airflow obstruction in established bronchiolitis obliterans syndrome. Am J Respir Crit Care Med 2005; 172: 772-775.

20. Ratjen F, Rjabko O, Kremens B. High-dose corticosteroid therapy for bronchiolitis obliterans after bone marrow transplantation in children. Bone Marrow Transplant 2005; 36: 135-138.

21. Pisanti A, Montella S, Vendemmia S, Pisanti C. Respiratory viral diseases and bronchiolitis in the first month of life. Pediatr Med Chir 2005; 27: 23-28.

22. Munoz FM. Pertussis in infants, children, and adolescents: diagnosis, treatment, and prevention. Semin Pediatr Infect Dis 2006; 17: 14-19. 